\title{
Study of Role of Surfactant Protein-D, Malondialdehyde, Protein Carbonyl and its Correlation with Airflow Obstruction (FEV1\% Predicted) in Patients with Smoker Chronic Obstructive Pulmonary Disease (COPD)
}

Rupali S Pawar* and Subhodini A Abhang

Department of Clinical Biochemistry, Byramjee Jeejeebhoy Government Medical College and Sassoon General Hospital, Pune, India

\begin{abstract}
Background: Smokers lungs are exposed to rich amounts of oxidants. Oxidative stress and inflammation are hallmarks of chronic obstructive pulmonary disease. SP-D is lung specific protein play important role in the lungs including regulation of surfactant homeostasis in the alveoli and modulation of host defense system in the lung. The aim of this study was to examine role of surfactant protein-D, malondiladehyde and protein carbonyl in smoker COPD patients and to see whether there is any correlation between pulmonary function test with MDA, PC and SP-D in COPD patients.
\end{abstract}

Materials and methods: We measured serum SP-D, MDA and PC in 30 smoker COPD patients, 30 non-smoker COPD patients and in 30 healthy controls by ELISA and spectrophotometric methods respectively.

Results: Serum levels of SP-D, MDA and PC were significantly higher in smoker COPD patients than non-smoker COPD patients. SP-D, MDA and PC were significantly increased in smoker COPD patients as compared to healthy controls. We found inverse correlation between FEV1\% predicted with SP-D, MDA and PC in COPD patients. MDA and PC were directly correlated with SP-D in COPD patients.

Conclusion: From these findings we conclude that deleterious effect tobacco smoke causes lipid and protein oxidation and lung tissue damage. Lung tissue injury causes release of SP-D in the blood stream. This is directly related with extent of injury and pulmonary function in COPD patients.

Keywords: Chronic Obstructive Pulmonary Disease (COPD); Surfactant Protein-D (SP-D); - Malondialdehyde (MDA); Protein Carbonyl (PC)

\section{Introduction}

Chronic Obstructive Pulmonary Disease (COPD) is a major global health problem affecting nearly 300 million people worldwide and killing 3 million individuals each year. It is the major cause of mortality that is rising 7 to 8 million per year by 2030 [1]. COPD cause 2.7 lac deaths every year in India [2]. COPD is a disease state characterized by airflow limitation that is not fully reversible. Airflow limitation is usually progressive and associated with abnormal inflammatory response of lungs to noxious particles and gases [3]. The major risk factor for the development of irreversible air flow limitation is tobacco smoking [4]. COPD remain undiagnosed in early stage of COPD it causes patients suffering from last stage of the disease. Delay diagnosis causes patients suffering from severe symptoms and progressive reduction in airflow rate and it causes decreased quality of life of patients and death. There is no treatment currently available for the reduction of progressive airflow limitation in patients with COPD. So, there is urgent need to detect the biomarker which helps in early detection of the disease.

Surfactant protein D is a lung specific biomarker. SP-D is a phosphoprotein and multi-molecular complex. There are four different types of surfactant proteins in the lungs SP-A, SP-B, SP-C and SP-D [5]. SP-D main function is to reduce the surface tension of lung alveoli and maintain the gas exchange ability during the process of the expiration and prevents the collapsing of lung alveoli [5]. In addition to this, pulmonary surfactant protein D has role in host defense system in the lungs [6]. SP-D is produced in alveolar type II epithelial cell and in Clara cells of the lungs [7]. Tobacco smoking is risk factor for the development of COPD in India [8]. The increased oxidant burden in smokers due to the fact that tobacco smoke contains $10^{6}$ free radicals/oxidants per puff and it consist of 4700 chemical compounds such as aldehydes, quinines, semiquinones, nitrosamines, nicotine, benzopyrene and other carcinogens, it is responsible for the development of chronic obstructive pulmonary disease and lung cancer [8-10].

The oxidants released from tobacco smoke, neutrophil and macrophages damages lipids and protein present on the epithelial cells of the lung tissues. Oxidants directly attack on polyunsaturated fatty acid which lies on the epithelial cell membranes of the lung tissues [11]. In this process of lipid oxidation malondialdehyde is formed. Malondialdehyde is the end product of lipid peroxidation and is the marker of oxidative damage of lipids in tissues [12]. Similar to lipids, oxidants release from tobacco smoke and of endogenous origin oxidizes -SH group of protein and converted protein into carbonylated form of proteins. Protein carbonyl is the marker of oxidative damage of proteins [13].

The aim of our study was to evaluate role of surfactant protein $\mathrm{D}$, malondialdehyde, protein carbonyl in smoker COPD patients and to see whether there is any relation between pulmonary function parameters with the biochemical markers in smoker COPD patients.

*Corresponding author: Rupali S Pawar, Department of Clinical Biochemistry, Byramjee Jeejeebhoy Government Medical College and Sassoon General Hospital, Pune, India, Tel: 8149196993; E-mail: rupali.pawar55@gmail.com

Received: July 24, 2017; Accepted: August 08, 2017; Published August 11, 2017

Citation: Pawar RS, Abhang SA (2017) Study of Role of Surfactant Protein-D Malondialdehyde, Protein Carbonyl and its Correlation with Airflow Obstruction (FEV1\% Predicted) in Patients with Smoker Chronic Obstructive Pulmonary Disease (COPD). Biochem Anal Biochem 6: 327. doi: 10.4172/2161-1009.1000327

Copyright: @ 2017 Pawar RS, et al. This is an open-access article distributed under the terms of the Creative Commons Attribution License, which permits unrestricted use, distribution, and reproduction in any medium, provided the original author and source are credited. 
Citation: Pawar RS, Abhang SA (2017) Study of Role of Surfactant Protein-D, Malondialdehyde, Protein Carbonyl and its Correlation with Airflow Obstruction (FEV1\% Predicted) in Patients with Smoker Chronic Obstructive Pulmonary Disease (COPD). Biochem Anal Biochem 6: 327. doi: 10.4172/2161-1009.1000327

Page 2 of 6

\section{Material and Methods}

The present study was carried out in Department of Biochemistry and Department of Pulmonary Medicine, B.J. Govt. Medical College and Sassoon General Hospital, Pune. The study protocol was approved by Institutional Ethical Committee [Ref. No. BJMC/IEC/Pharmac/ D1210133-35]. The study period was in between Jan 2011 and December 2014

\section{Study design and sampling}

The present study was a case control study. The selection of sample was done by simple random sampling.

\section{Selection of healthy controls}

Control group consisted of 60 age and sex-matched healthy volunteers with no history of COPD, confirmed by spirometric tests performed during medical examination prior to the study.

\section{Selection of study groups}

COPD diagnosis for all patients included in the study was made by the evaluation of pulmonary function tests by using spirometer. Study subjects were aged in between of 40-75 yrs. Patients with COPD were included if they had a post-bronchodilator forced expiratory volume in one seconds (FEV1)/force vital capacity (FVC) $<70 \%$ after $400 \mu \mathrm{g}$ of inhaled salbutamol. Study comprises 30 patients of smoker with COPD, 30 patients of non-smoker with COPD and 30 ages and sex matched healthy controls. According to GOLD (Global Initiative for Obstructive Lung Disease) guideline COPD patients with whom postbronchodilator values of $\mathrm{FEV}_{1} \%$ predicted $<12 \%$, with $\mathrm{FEV}_{1} / \mathrm{FVC} \%$ ratio $<70 \%$ were included in the study.

\section{Inclusion criteria}

1. The patient was willing to enter the study (i.e., patients' written consent).

2. Smoking history of $>20$ packs per year.

3. Post bronchodilator increase in FEV $1<12 \%$

4. Patients were clinically stable (no exacerbation for 2 months) at the time of the evaluation.

5. Patients age $>40$ yrs.

\section{Exclusion criteria for controls and COPD patient's groups}

Patients who were suffering from or who were known to have tuberculosis, pneumonia, asthma, bronchiectasis, lung cancer, interstitial lung diseases, respiratory failure, cardiac failure, diabetes mellitus, hepatic disease, renal disease and who had any recent surgical intervention and who were unable to performed lung function test were excluded from our COPD patients group. Healthy individual with any past history of lung/respiratory disease or with abnormal lung function test were excluded from Control group.

\section{Collection of blood samples}

Under aseptic condition and with prior written consent of the subject, $5 \mathrm{ml}$ of blood was collected in a plain bulb from large peripheral vein, after overnight fasting and it allowed to clot for $1 \mathrm{hr}$. Serum was separated by centrifugation at $3000 \mathrm{rpm}$ for $10 \mathrm{~min}$. at room temperature, separated serum was aliquot and stored at $-80^{\circ} \mathrm{C}$ until the analysis and was used for the estimation of biochemical parameters such as serum malondialdehyde, protein carbonyl and lung surfactant protein -D.

\section{Methods}

\section{Estimation of serum malondialdehyde}

Serum malondialdehyde was determined by Buege and Aust method. It was expressed as $\mathrm{nmol} / \mathrm{ml}[14]$.

\section{Estimation of serum protein carbonyl}

Serum protein carbonyl was determined by Levin et al. It was expressed as $\mathrm{nmol} / \mathrm{mg}$ of proteins [15]. Protein concentration in $\mathrm{mg} /$ $\mathrm{ml}$ was determined by Bradfoed method [16].

\section{Estimation of serum surfactant protein D}

Serum surfactant protein-D was measured by ELISA method. In the BioVendor Human Surfactant Protein D ELISA, Standards, Quality Controls and samples are incubated in micro plate wells pre-coated with monoclonal anti-human surfactant protein D antibody. After 120 minutes incubation and washing, biotin labeled monoclonal antihuman SP-D antibody is added and incubated with the captured SP-D for 60 minutes. After another washing, Streptavidin-HRP Conjugate is added. After 60 minutes incubation and the last washing steps, the remaining HRP conjugate is allowed to react with the Substrate Solution (TMB). The reaction is stopped by addition of acidic solution and absorbance of the resulting yellow product is measured. The absorbance is proportional to the concentration of surfactant protein D. A standard curve is constructed by plotting absorbance values against concentrations of standards and concentrations of unknown samples are determined using this standard curve [17].

\section{Pulmonary function test}

Pulmonary Function test was done by using Spirometer. Measurement of Forced Vital Capacity and Forced Expiratory Volume was done in First seconds. The FEV $/ F V C$ is calculated using the maximum $\mathrm{FEV}_{1}$ and $\mathrm{FVC}$ from the technically acceptable, though not from the same curves. Values of $\mathrm{FEV}_{1}, \mathrm{FVC}$ and $\mathrm{FEV}_{1} / \mathrm{FVC} \%$ ratio have been noted. The Data was obtained from the printer, attached to spirometer.

\section{Results}

Table 1 shows irrespective of age and sex, the lung function parameters were significantly decreased in patient with smoker COPD, in patients with non-smoker COPD as compared to healthy controls (Table 1).

Table 2 shows serum levels of SP-D were significantly increase in patients with smoker COPD and non-smoker COPD as compared to healthy controls. Similar to surfactant protein-D, serum levels of malondialdehyde and protein carbonyl were significantly increased in patients with smoker COPD and in patients with non-smoker COPD as compared to healthy controls (Table 2).

Table 3 shows there was significant positive correlation between serum SP-D with MDA and protein carbonyl in patients with smoker COPD, patients with non-smoker COPD. SP-D, MDA and PC were negatively correlated with FEV1\% predicted and with FEV1/FVC \% ratio in stages of COPD patients (Table 3 ).

In Table 4 values of ROC curve analysis of SP-D, MDA and PC were depicted. The cut-off level of serum lung surfactant protein-D $143.12 \mathrm{ng} / \mathrm{ml}$ in COPD patients (AUC $=0.930, \mathrm{SE}=0.03,95 \% \mathrm{CI}=0.85$ to $0.97, \mathrm{P}<0.0001$ ) were decided by using ROC Curve analysis. At 
Citation: Pawar RS, Abhang SA (2017) Study of Role of Surfactant Protein-D, Malondialdehyde, Protein Carbonyl and its Correlation with Airflow Obstruction (FEV1\% Predicted) in Patients with Smoker Chronic Obstructive Pulmonary Disease (COPD). Biochem Anal Biochem 6: 327. doi: $10.4172 / 2161-1009.1000327$

Page 3 of 6

\begin{tabular}{|c|c|c|c|}
\hline Variables & Healthy Controls $(n=30)$ & $\begin{array}{l}\text { Smoker with COPD patients } \\
\qquad(n=30)\end{array}$ & Non-smoker with COPD patients $(n=30)$ \\
\hline Age & $52.93 \pm 9.08$ & $66.3 \pm 4.3^{a}$ & $62.53 \pm 5.79^{\mathrm{bc}}$ \\
\hline Smoking history (pack years) & --- & $52.1 \pm 4.74$ & --- \\
\hline $\mathrm{FEV}_{1} \%$ predicted & $105.03 \pm 13.08$ & $22.06 \pm 4.3^{d}$ & $41.9 \pm 6.18^{\text {ef }}$ \\
\hline $\mathrm{FEV}_{1} / \mathrm{FVC} \%$ ratio & $100.03 \pm 7.47$ & $56.85 \pm 5.9^{9}$ & $60.1 \pm 4.78^{\text {hi }}$ \\
\hline \multicolumn{4}{|c|}{ 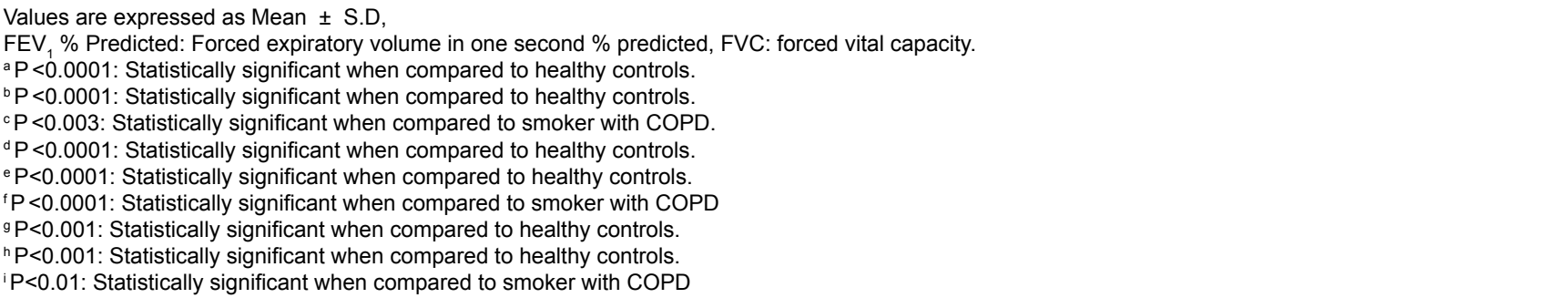 } \\
\hline
\end{tabular}

Table 1: Demographic characteristic of patients with smoker COPD, patients with non-smoker COPD and control groups.

\begin{tabular}{|c|c|c|c|}
\hline Biochemical Parameters & $\begin{array}{l}\text { Healthy Controls } \\
\qquad(n=30)\end{array}$ & COPD patients with smoker $(n=30)$ & COPD patients with Non-smoker $(n=30)$ \\
\hline Serum Surfactant protein-D (ng/ml) & $115.04 \pm 50.24$ & $230.48 \pm 45.08^{a}$ & $207.43 \pm 44.63^{\mathrm{bc}}$ \\
\hline Serum Malondialdehyde $(\mathrm{nmol} / \mathrm{ml})$ & $4.19 \pm 1.79$ & $11.9 \pm 1.21^{\mathrm{d}}$ & $9.6 \pm 1.59^{\text {ef }}$ \\
\hline $\begin{array}{l}\text { Serum protein carbonyl } \\
\text { (ng/mg of proteins) }\end{array}$ & $3.50 \pm 1.87$ & $11.08 \pm 2.5^{g}$ & $9.07 \pm 2.49^{\text {hi }}$ \\
\hline $\begin{array}{l}\text { Values are expressed as Mean } \pm S . D \text {, } \\
\text { a } \mathrm{P}=0.0001 \text { : statistically significant whe } \\
\text { b } \mathrm{P}=0.0001 \text { : statistically significant wh } \\
\text { c } \mathrm{P}=0.025 \text { : statistically significant wher } \\
\text { d } \mathrm{P}=0.0001 \text { : } \text { statistically significant whe } \\
\text { e } \mathrm{P}=0.0001 \text { : } \text { statistically significant whe } \\
\text { f } \mathrm{P}=0.0001 \text { : statistically significant whe } \\
\text { g } \mathrm{P}=0.0001 \text { : statistically significant whe } \\
\text { h } \mathrm{P}=0.0001 \text { : statistically significant whe }\end{array}$ & $\begin{array}{l}\text { de, PC: Protein Carl } \\
\text { y controls. } \\
\text { ny controls. } \\
\text { with COPD. } \\
\text { y controls. } \\
\text { y controls. } \\
\text { r with COPD. } \\
\text { y controls. } \\
\text { y controls. }\end{array}$ & SP-D: Surfactant Protein-D. & \\
\hline
\end{tabular}

Table 2: Serum levels of surfactant protein D, malondialdehyde, protein carbonyl in COPD patients with smoker, COPD patients with non-smoker and healthy controls.

\begin{tabular}{|c|c|c|c|c|c|c|}
\hline \multirow[t]{2}{*}{ Correlations } & \multicolumn{2}{|c|}{$\begin{array}{l}\text { Healthy Controls } \\
\qquad(n=30)\end{array}$} & \multicolumn{2}{|c|}{$\begin{array}{l}\text { COPD patients } \\
\text { with smokers } \\
(n=30)\end{array}$} & \multicolumn{2}{|c|}{$\begin{array}{l}\text { COPD patients } \\
\text { with non-smokers } \\
(n=30)\end{array}$} \\
\hline & $r$ value & $P$ value & $r$ value & $P$ value & r value & $P$ value \\
\hline SP-D-FEV $1 \%$ Predicted & -0.024 & 0.899 & -0.693 & 0.0001 & -0.493 & 0.005 \\
\hline SP-D- FEV $/$ /FVC \% ratio & -0.097 & 0.610 & -0.477 & 0.007 & -0.379 & 0.03 \\
\hline MDA-FEV ${ }_{1} \%$ Predicted & +0.047 & 0.803 & -0.825 & 0.0001 & -0.583 & 0.0007 \\
\hline MDA-FEV $/$ /FVC $\%$ Predicted & -0.156 & 0.410 & -0.732 & 0.0001 & -0.438 & 0.01 \\
\hline PC- $\mathrm{FEV}_{1} \%$ Predicted & +0.152 & 0.422 & -0.582 & 0.0001 & -0.534 & 0.002 \\
\hline PC- $\mathrm{FEV}_{1} / \mathrm{FVC} \%$ ratio & +0.150 & 0.428 & -0.480 & 0.0001 & -0.405 & 0.02 \\
\hline SP-D- MDA & -0.113 & 0.389 & +0.391 & 0.002 & +0.585 & 0.001 \\
\hline SP-D-PC & -0.031 & 0.814 & +0.298 & 0.02 & +0.489 & 0.001 \\
\hline
\end{tabular}

Table 3: Correlation of surfactant protein-D, Malondialdehyde (MDA) and Protein Carbonyl (PC) with pulmonary function test markers (FEV $\%$ predicted and FEV $/ F V C \%$ ratio) in COPD patients with smoker, COPD patients with non-smoker and in healthy controls.

this cut-off level of serum lung surfactant protein-D, we achieved a sensitivity of $93.33 \%$ ( $95 \% \mathrm{CI}=83.8$ to 98.2 ) and specificity of $83.33 \%$ (95\% CI=65.3 to 94.4). Similarly, the cut-off level serum MDA $7.65 \mathrm{ng} /$ $\mathrm{ml}(\mathrm{AUC}=0.998, \mathrm{SE}=0.00,95 \% \mathrm{CI}=0.95$ to $1.00, \mathrm{P}<0.0001)$ for $\mathrm{COPD}$ patients were decided by using ROC Curve analysis. At this cut-off level of serum MDA, we achieved a sensitivity of $96.67 \%$ (95\% CI $=88.5$ to 99.6$)$ and specificity of $100 \%$ (95\% CI=88.4 to 100). Similarly, for serum protein carbonyl the cut-off level $5.91 \mathrm{ng} / \mathrm{mg}$ of proteins for COPD patients $(\mathrm{AUC}=0.981, \mathrm{SE}=0.01,95 \% \mathrm{CI}=0.92$ to $0.99, \mathrm{P}<0.0001$ ) were decided by using ROC Curve analysis. At this cut-off level of serum protein carbonyl, we achieved a sensitivity of $98.33 \%(95 \%$ $\mathrm{CI}=91.1$ to 100$)$ and specificity of $93.33 \%$ ( $95 \% \mathrm{CI}=77.9$ to 99.2 ). These results indicate that increase in cut off levels of serum lung surfactant protein-D, MDA and PC increases the sensitivity and specificity. The values of area under ROC curve for above mention parameters were increases in the presence of the disease. From our findings we suggest that cut-off levels of lung surfactant protein-D, malondialdehyde and protein carbonyl can be used as good marker to diagnose the COPD patients from healthy controls (Table 4).

\section{Discussion}

In present study, we evaluated plasma levels of SP-D, malondialdehyde and protein carbonyl in patients with smoker COPD and non-smoker COPD. All these putative markers have been suggested to associate with COPD. Tobacco smoking is the major risk factor for the development of COPD in India. Tobacco smoke contains enormous quantity of free radicals; these free radicals directly penetrate into the respiratory tract and reach the lung alveoli. It causes lung tissue 
Citation: Pawar RS, Abhang SA (2017) Study of Role of Surfactant Protein-D, Malondialdehyde, Protein Carbonyl and its Correlation with Airflow Obstruction (FEV1\% Predicted) in Patients with Smoker Chronic Obstructive Pulmonary Disease (COPD). Biochem Anal Biochem 6: 327. doi: 10.4172/2161-1009.1000327

Page 4 of 6

\begin{tabular}{|c|c|c|c|c|c|c|c|c|c|}
\hline Variables & AUC & SE & $\begin{array}{l}\text { Cut off } \\
\text { point }\end{array}$ & $95 \% \mathrm{Cl}$ & P-value & Sensitivity & $95 \% \mathrm{Cl}$ & Specificity & $95 \% \mathrm{Cl}$ \\
\hline SP-D & 0.930 & 0.032 & 143.12 & 0.85 to 0.97 & 0.0001 & $93.33 \%$ & $\begin{array}{l}83.8 \text { to } \\
98.2 \%\end{array}$ & $83.33 \%$ & $\begin{array}{l}65.3 \text { to } \\
94.4 \%\end{array}$ \\
\hline MDA & 0.998 & 0.00 & 7.654 & 0.95 to 1.00 & 0.0001 & $96.67 \%$ & $\begin{array}{l}88.5 \text { to } \\
99.6 \%\end{array}$ & $100 \%$ & $\begin{array}{c}88.4 \text { to } \\
100 \%\end{array}$ \\
\hline PC & 0.981 & 0.01 & 5.918 & 0.92 to 0.99 & 0.0001 & $98.33 \%$ & $\begin{array}{l}91.1 \text { to } \\
100 \%\end{array}$ & $93.33 \%$ & $\begin{array}{l}77.9 \text { to } \\
99.2 \%\end{array}$ \\
\hline
\end{tabular}

Table 4: Area under ROC curve values for SP-D, MDA and PC in COPD patients.

damage and inflammation [18]. Sur factant protein-D is lung specific protein. Surfactant protein-D is a large collagenous glyco-protein synthesized mainly in type II epithelial cells and in Clara cells of the lungs [19]. Serum SP-D has been identified as potential biomarker for some pulmonary disease, such as respiratory syncytial virus bronchiolitis [20], idiopathic interstitial fibrosis [21], acute respiratory distress syndrome [22] and allergic broncho pulmonary aspergillosis [23]. In our study, we found significantly increased levels of SP-D in patients with smoker COPD and in patients with non-smoker COPD as compared to healthy controls. This finding was in line with a large study of patients with and without COPD, where the ECLIPSE investigator found higher serum SP-D levels in COPD patients than in healthy controls [24]. In our study we found increase levels of SP-D in patients with smoker COPD and non-smoker COPD this might be due to deleterious effects oxidants from tobacco smoke and oxidants originated from endogenous sources on lung tissue cause release of SP-D in blood stream. The increased level of SP-D in the blood stream depends on the extent of injury to the lung tissue and is directly related to pulmonary function [25-27]. In our study we obtain inverse correlation between SP-D with FEV1\% predicted and FEV1/FVC \% ratio in COPD patients. However, the ECLIPSE investigator failed to find a significant relationship between FEV1\% predicted and SP-D in COPD patients [24]. In spite of that, our findings were in line with those of Sin et al. [28] who showed an inverse correlation between circulating SP-D and FEV1 in COPD patients and those with Winkler et al. [29], who found an inverse correlation of SP-D levels with FEV1/FVC in COPD. Consistently, we observed a positive correlation between serum SP-D with MDA and PC in patients with COPD. Thus SP-D may be used as promising marker for evaluating degree of severity in COPD patients and evaluating the treatment response (Figure 1).

Malondialdehyde is the end product of lipid peroxidation. Malondialdehyde is generally use as a marker of oxidative stress [12]. In this study, we observed higher level MDA, a last product of lipid peroxidation in COPD as compared with healthy con trols. There was also statistically significant difference between smoker COPD patients and non-smoker COPD patients. These data support the view that oxidative stress has an important role in COPD and that smoking enhances oxidative stress. Our findings are in line with Rahman et al. who reported increase levels lipid peroxidation and decrease antioxidant capacity in COPD patients and in smokers [30]. Colak et al. also showed MDA levels were higher in COPD patients than healthy controls [31]. Calikoglu et al. found increased levels of serum MDA in exacerbated COPD patients [32] (Figure 2).

Proteins are present abundantly on the cell membranes. It can scavenge $50-75 \%$ of reactive radicals such as $\mathrm{OH}^{\bullet}$ [33]. Similar to lipids, proteins are also targeted by reactive oxygen species. Reactive oxygen species induced protein modifications can result in unfolding or alteration of protein structure was reported by Cabiscol and Ros in 2006 [34]. Protein carbonylation is an irreversible and non-enzymatic reaction. Irreversible protein modification can lead to inactivation of

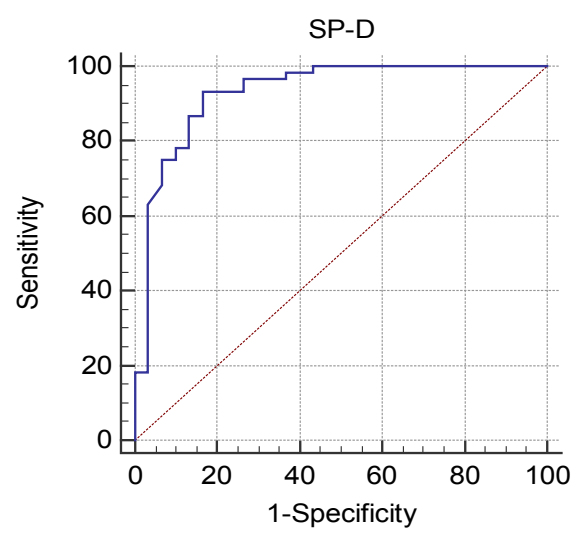

Figure 1: ROC curve analysis of SP-D in COPD patients

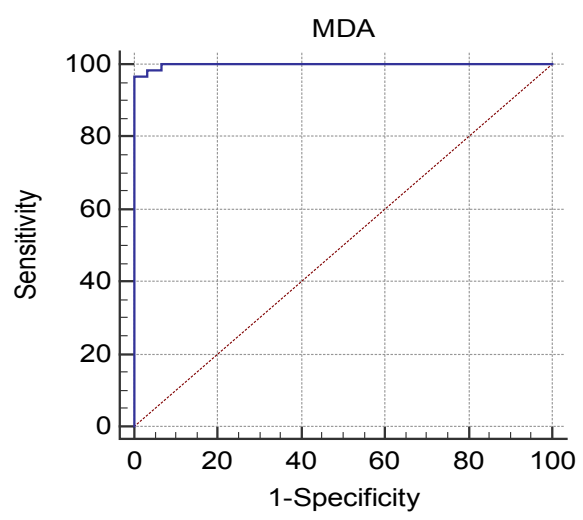

Figure 2: ROC curve analysis of MDA in COPD patients.

various proteins, loss of their structure and function and could have detrimental effects on the cell [35]. In our study we observed increased levels of protein carbonyl in smoker COPD patients as compared to healthy controls. There was also statistically significant difference observed between serum levels of protein carbonyl in smoker COPD and in non-smoker COPD patients. We observed increased levels of protein carbonyl in COPD patients this might be due to increase oxidation of proteins when exposed to reactive oxygen species. Increased oxidative stress leads to increased production of protein carbonyl in COPD patients [36]. Our findings are in line with study of Yessica et al. who reported increased level of protein carbonyl in COPD patients [37]. In contrast to our study, Mesia- Vela et al. have reported no significant change in the level of protein carbonyl in COPD patients [38]. In our study we observed inverse correlation between MDA and PC with FEV1\% predicted and FEV1/FVC ratio in patients with smoker COPD and in patients with non-smoker COPD (Table 3). We are first to report a positive correlation between MDA with SP-D in smoker and non-smoker COPD patients (Table 3). Normally surfactant protein-D 
Citation: Pawar RS, Abhang SA (2017) Study of Role of Surfactant Protein-D, Malondialdehyde, Protein Carbonyl and its Correlation with Airflow Obstruction (FEV1\% Predicted) in Patients with Smoker Chronic Obstructive Pulmonary Disease (COPD). Biochem Anal Biochem 6: 327. doi: $10.4172 / 2161-1009.1000327$

Page 5 of 6

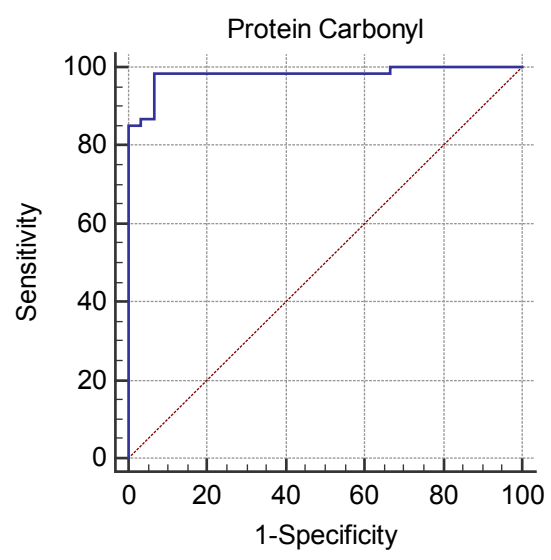

Figure 3: ROC curve analysis of protein carbonyl in COPD patients.

inhibits lipid peroxidation. In increased oxidative stress condition levels of MDA were increased, this causes loss of permeability of alveolar epithelial cells of lungs. Therefore SP-D from lungs may leak out in blood circulation and there levels were increased in COPD patients. Hence, we observed positive correlation between SP-D with MDA in COPD. In present study serum SP-D also correlated positively with serum protein carbonyl in COPD patients (Table 3 and Figure 3).

\section{Conclusion}

From these findings we conclude that deleterious effect of tobacco smoke causes lipid and protein oxidation which lies on alveolar epithelial cells in smoker COPD patients. That leads to lung tissue damage. Lung tissue injury causes release of SP-D in the blood stream. Increase levels of SP-D, MDA and PC in serum is directly related with the degree of injury and impairment of lung function in COPD patients. SP-D, MDA and PC can be used as good marker to detect the severity in COPD patients.

\section{Strengths}

We are the first here to report the correlation between serum levels of surfactant protein-D, MDA with the markers of airflow obstruction FEV1\% predicted, FEV1/FVC\% ratio in smoker and non-smoker COPD patients.

\section{Limitations}

The present study was carried out with a relatively small number of subjects. It would be better to perform this study with greater number of subject in order to determine the difference between the analysis of biochemical and lung function parameters of COPD patients and healthy control groups more clearly.

\section{Acknowledgments}

Author would like to thanks the patients who participated in this study as well as the personnel of Department of Pulmonary Medicine and Department of Biochemistry of B. J. Govt. Medical College and Sassoon General Hospital, Pune.

\section{References}

1. World Health Organization (2013) The 10 leading causes of deaths in the world during 2000 and 2011. WHO report.

2. Khandelwal MK, Maheshwari VD, Garg S, Kumar K, Gupta R, et al. (2013) Six minutes' walk distance: Correlation with spirometric and clinical parameters in COPD. Int J Healthcare of Biomed Research 3: 217-226.

3. Foley RJ, Zu-Wallack R (2001) The impact of nutritional depletion in chronic obstructive pulmonary disease. J Cardiopulm Rehabil 21:1041-1052
4. Eisner MD, Anthonisen N, Coultas D, Kuenzil N, Perez-Padilla R, et al. (2010) An Official American Thoracic Society public Policy Statement: Novel risk factors and the global burden of chronic obstructive pulmonary disease. Am. J. Respir. Crit Care Med 182: 693-718.

5. Person A, Rust K, Chang D, Moxley M, Longmore W, et al. (1988) CP4: A pneumocyte-derived collagenous surfactant-associated protein-evidence fo heterogeneity of collagenous surfactant protein. Biochemistry 27: 8576-8578.

6. Van Iwaarden F, Welmers B, Verhoef J, Haagsman HP, Van Golde LMG (1990) Pulmonary surfactant protein A enhances the host-defense mechanism of rat alveolar macrophages. Am J Respir Cell Mol Biol 2: 91-98.

7. Palaniyar N, Zhang L, Kuzmenko A, Ikegami M, Wan S, et al. (2002) The role of pulmonary collectin N-terminal domains in surfactant structure, function and homeostasis in vivo. J Biol Chem 277: 26971-26979.

8. Foronjy R, D'Armiento J (2006) The effect of cigarette smoke-derived oxidants on the inflammatory response of the lung. Clinical and Applied Immunology Review $6: 53-72$.

9. Pryor WA, Stone K (1993) Oxidants in cigarette smoke. Radicals, hydrogen peroxide peroxynitrate and peroxynitrite. Ann NY Acad Sci 686: 12-27.

10. Langen RCJ, Korn SH, Wouters EFM (2003) ROS in the local and systemic pathogenesis of COPD. Free Radic Biol Med 35: 226-235.

11. Thorley AJ, Tetley TD (2007) Pulmonary epithelium, cigarette smoke and chronic obstructive pulmonary disease. Int J Chron Obstruct Pulmon Dis 2: 409-428.

12. Rueff J, Laires A, Bras A, Borba H, Chaveca T, et al. (1989) DNA damage and oxygen species. In DNA repair mechanisms and their biological implications in mammalian cells. Plenum Press, New York, USA. p. 171-181.

13. Colombo G, Aldini G, Orioli M, Giustarini D, Gornati R, et al. (2010) Water soluble $\alpha, \beta$-unsaturated aldehydes of cigarette smoke induce carbonylation of human serum albumin. Antioxid Redox Signal 12: 3.

14. Buege JA, Aust SD (1978) Microsomal lipid peroxidation. Method Enzymol 52 302-310.

15. Levin RL, Garland D, Oliver CN, Amici A, Climet I, et al. (1990) Determination of carbonyl content in oxidatively modified proteins. Meth Enzymol 186: 464-478.

16. Bradfoed MM (1976) A rapid and sensitive method for the quantitation of microgram of protein utilizing the principle of protein dye binding. Analy Bioch 72: $248-254$

17. Inoue T, Matsuura E, Nagata A (1994) Enzyme linked immunosorbent assay for human pulmonary surfactant protein D. J Immun Methods 173: 157-164.

18. Paul K, Rahman I (2006) Oxidative stress in asthma and COPD: Antioxidant as a therapeutic strategy. Pharmacol Ther 1: 476-494.

19. Persson A, Rust K, Chang D, Moxley M, Longmore W, et al. (1988) CP4: A pneumocystis-derived collagenous surfactant-associated protein-evidence for heterogeneity of collganenous surfactant proteins. Biochemistry 27: 85768584.

20. Ohnishi H, Yokoyama A, Kondo K, Hamada H, Abe M, et al. (2002) Comparative study of KL-6, surfactant protein-A, surfactant protein $-D$ and monocyte chemoattractant protein-1 as serum markers for interstitial lung diseases. Am J Respir Crit Care Med 165: 378-381.

21. Kowasaki Y, Endo K, Suyama K, Sato M, Ito M, et al. (2011) Serum SP-D levels as a biomarker of lung injury in respiratory syncytial virus bronchiolitis. Pediatr Pulmonol 46: 18-22.

22. Eisener MD, Parsons P, Matthay MA (2003) Plasma surfactant protein levels and clinical outcomes in patients with acute lung injury. Thorax 58: 983-988.

23. Krane M, Griese M (2003) Surfactant protein D in serum from patient with allergic bronchopulmonary aspergillosis. Eur Respir J 22: 592-595.

24. Lomas DA, Silverman EK, Edwards LD (2009) Serum surfactant protein D is steroid sensitive and associated with exacerbation of CODP. Eur Respir 34: 95-102.

25. Doyle IR, Nicholas TE, Bersten AD (1997) Surfactant proteins A and B are elevated in plasma of patients with acute respiratory failure. Am Respir Crit Care Med 12004: 1227-1229.

26. Robin M, Dong P, Hermans C, Bernard A, Bersten AD, et al. (2002) Serum levels of $\mathrm{CC} 1$, SP-S and SP-B reflect tobacco-smoke exposure in asymptomatic subjects. Eur Respir J 20: 1152-1161. 
Citation: Pawar RS, Abhang SA (2017) Study of Role of Surfactant Protein-D, Malondialdehyde, Protein Carbonyl and its Correlation with Airflow Obstruction (FEV1\% Predicted) in Patients with Smoker Chronic Obstructive Pulmonary Disease (COPD). Biochem Anal Biochem 6: 327. doi: $10.4172 / 2161-1009.1000327$

27. Hermans C, Bernard A (1999) Lung epithelium-specific proteins: characteristics and potential applications as markers. Am J Respir Crit Care Med 159: 646-678

28. Sin DD, Leung R, Gan WQ, Man SP (2007) Circulating surfactant protein-D as a potential lung-specific biomarker of health outcomes in COPD: A pilot study. BMC Pulm Med 7: 13.

29. Winkler C, Atochina-Vasserman EN, Holz O, Beers MF, Erpenbeck VJ, et al. (2001) Comprehensive characterization of pulmonary and serum surfactant protein D in COPD. Respir Res 12: 29.

30. Rahman I, Morrison D, Donaldson K, Mac Nee W (1996) Systemic oxidative stress in asthma, COPD and smokers. Am J Respir Crit Care Med 154: 10551060.

31. Colak O, Alatas O, Akyuz F (1995) Antioxidant status in chronic obstructive pulmonary disease. Tr J Med S Sci 24: 305-307.

32. Calikoglu M, Unlu A, Tamer L, Ercan B, Buğdayci R, et al. (2002) The levels of serum vitamin $\mathrm{C}$, malondiladehyde and erythrocyte reduced glutathione in chronic pulmonary disease and in healthy smokers. Clin Chem Lab Med 40: 1028-1031.
33. Davis MJ, Fu S, Wang H, Dean RT (1999) Stable markers of oxidant damage to proteins and their application in study of human disease. Free Radic Bio Med 27: 1151-1161.

34. Cabiscol E, Ros J (2006) Oxidative damage to proteins: Structural modifications and consequences in cell function. In : Dalle- Donne I, Scaloni A, butterfiels DA (eds). Redox proteiomics: From protein modifications to cellular dysfunction and disease. John Wiley \& Sons, Inc., Hoboken, NY, USA. p. 399-471.

35. Dalle-Donne I, Aldini G, Carini M, Colombo R, Rossi R, et al. (2006) Protein carbonylation, cellular dysfunction and disease progression. J Cell Mol Med 10: 389-406.

36. MacNee W (2005) Oxidant and COPD. Curr Drug Target Inflam and Allergy 4: $627-641$

37. Yessica D, Torres R, Maria L, Guillen G, Ivonne M, et al. (2009) Correlation of plasma protein carbonyl and C-reactive protein with GOLD stage progression in COPD patients. The Open Respir Medi J 3: 61-66

38. Mesia-Vela S, Yeh CC, Austin JHM, Dounel M, Powell CA, et al. (2008) Plasma carbonyls do not correlate with lung function or computed tomography measures of lung density in older smokers. Biomarkers 13: 422-434. 